\title{
ECONOMIC EVALUATION OF NANO AND ORGANIC FERTILISERS AS AN ALTERNATIVE SOURCE TO CHEMICAL FERTILISERS ON CARUM CARVI L. PLANT YIELD AND COMPONENTS
}

\author{
ABDEL WAHAB M. MAHMOUD*, EL-ATTAR A.B, ABEER A. MAHMOUD \\ ${ }^{1}$ Cairo University, Giza, Egypt
}

MAHMOUD, A.W.M. - EL-ATTAR, A.B. - MAHMOUD, A.A.: Economic evaluation of nano and organic fertilisers as an alternative source to chemical fertilisers on Carum carvi L. plant yield and components. Agriculture (Pol’nohospodárstvo), vol. 63, 2017, no. 1, p. 33-49.

To show the benefits of organic agriculture, safe and sustainable production, the present research was performed in an open field (new reclaimed area of desert) of Wadi El-Notron, Beheira Governorate, Egypt, for two successive years (2013 and 2014) aimed at a better understanding and to investigate the role of alternative source of chemical fertilisers represented by humic substances, natural nano-zeolite-loaded nitrogen and biofertilisers (HNB) on yield, morphological, leaf and seed anatomy, chemical compositions reflected in macro and micro nutrients, indigenous hormones, plant pigments, total carbohydrates, ascorbic acid, thiamine, total phenolics, total flavonoids, total fatty acids, oil yield and constituents of caraway (Carum carvi L.) plants. Our results revealed that plants receiving a combination treatment (HNB) recorded significant increases over control in both growing seasons. Moreover, economic evaluation reflects the profound influence of combination treatment $(\mathrm{HNB})$ that realized the maximum gross income and minimum production cost. These findings emphasize the magnitude of the role of natural soil additions and organic fertilisers in mitigating environmental pollution while providing safe production and also minimizing total costs of chemical fertilisers.

Key words: biofertilisers, caraway, economic evaluation, humic, hormones, zeolite, oil yield

In the last few years, utilization of fertilisers has risen exponentially throughout the world, causing serious environmental problems. Overload application of fertilisers may accumulate heavy metals in soil and plant system; hence they possibly enter the food chain. Nitrogen and phosphorus as chemical fertilisers applied to farming land can provide valuable plant nutrients. On the other hand, if not handled in the right way, $\mathrm{N}$ and $\mathrm{P}$ can have harmful environmental effects. Meanwhile, the total nitrogen demand for agriculture all over the world is estimated to be 112.9 million tons for 2015. In the meantime, total loss in nitrogen fertiliser application is about $60-75 \%$ (FAO 2013). Therefore, a greater part of nitrogen fertilisers are not absorbed, and they consequently pollute both underground and surface water. Intemperance $\mathrm{N}$ in the form of nitrate may infiltrate the groundwater, causing nitrate contamination, which causes blue baby syndrome disease (Fewtrell 2004). Additionally, an overdose of $\mathrm{N}$ and $\mathrm{P}$ fertilisers leads to eutrophication, subsequently creating anoxic areas called dead zones (Savci 2012). Generally, there has been an increasing awareness about the undesirable impact of artificial or petrochemical fertilisers on the environment, over and above the potentially dangerous effects of

Mohamed Abdel Wahab Mahmoud, Assistant professor (*Corresponding author) Cairo University, Faculty of agriculture, Plant physiology department, 12613 Giza,Egypt. E-mail: mohamedabdelwahab@cu.edu.eg

Asmaa Badr El-Din El-Attar, Assistant professor, Cairo University, Faculty of agriculture, Ornamental department, 12613 Giza, Egypt.

Abeer Abdel Rahman Mahmoud, Associate professor, Cairo University, Faculty of agriculture, Plant physiology department, 12613 Giza, Egypt. 
chemical residues due to heavy metal accumulation in plant tissues on human health and animal consumers.

An example an aromatic plant is caraway (Carum carvi L.), which belongs to Apiaceae family, indigenous to northern Africa, Europe, and western Asia. The caraway fruit is a schizocarp, which at harvest is separated into two equally shared parts called "seeds" (Oosterhaven et al. 1995). Caraway plant is an important source of monoterpene, as it has carvone and limonene as its major monoterpene components. The seeds are used as a spice in food due to its pleasant flavour, and traditionally used as a remedy for dyspepsia and intestinal colic and antispasmodic (Lawless 1992) problems. Caraway essential oil has antioxidant (Yu et al. 2005; Wojdylo et al. 2007), antibacterial (Alzoreky \& Nakahara 2003; Shan et al. 2007), fungicidal (Soliman \& Badeaa 2002) and insecticidal (Lopez et al. 2008) properties. It has a lethal effect on mites (El-Zemity et al. 2006) and also has larvicidal (Pitasawat et al. 2007) and molluscicidal activities (Kumar \& Singh 2006). Focusing on organic farming, we found that carvone is applied as a natural inhibitor of vegetative growth, mostly with stored onions and potatoes
(Hartmans et al. 1995; Oosterhaven et al. 1995). Also, essential oil plays a vital role in pharmaceutical applications as medicine for humans due to its diuretic (Lahlou et al. 2007), anti-hyperglycaemic (Ene et al. 2008), anti-hypercholesterol (Lemhadri et al. 2006) plus anti-cancerous (Naderi-Kalali et al. 2005; Kamaleeswari et al. 2006) properties.

Nanoscience involves the development of fundamental understanding applied to nanoscale phenomena such as physical properties of materials and objects such as clusters of atoms, molecules and biological structures. Nanoscience is sometimes further broken down into sub-disciplines such as nanochemistry, nanophysics and nanobiology. Nanoparticles, natural or synthetic, are materials that vary in size between 1 and $100 \mathrm{~nm}$ (Kelkar et al. 2014). Nanotechnology opens up a large scope for novel applications in the fields of biotechnology, agriculture, fertiliser industries since nanoparticles have unique physico-chemical properties because of their high surface area, high reactivity, tunable pore size and particle morphology (Siddiqui et al. 2015).

The present research aims at a better understanding and investigation of the role of alternative sources of chemical fertilisers using natural zeolite in the

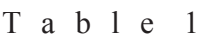

Some physical and chemical properties of experimental site

\begin{tabular}{|c|c|c|c|}
\hline \multicolumn{2}{|c|}{ Physical properties } & \multicolumn{2}{|c|}{ Chemical properties } \\
\hline \multicolumn{2}{|l|}{ Particle size distribution [\%] } & Electrical conductivity (EC) $[\mathrm{dS} / \mathrm{m}]$ & 1.68 \\
\hline \multirow{2}{*}{$\begin{array}{l}\text { Coarse sand 2000-200 } \mu \\
\text { Fine sand } 200-20 \mu\end{array}$} & \multirow{2}{*}{$\begin{array}{l}80.20 \\
12.50\end{array}$} & $\mathrm{pH}(1: 2.5)$ soil : water suspension & 7.68 \\
\hline & & \multicolumn{2}{|c|}{ Soluble cations $[\mathrm{meq} / \mathrm{l}]$ : } \\
\hline Silt $20-2 \mu$ & 4.25 & $\mathrm{Ca}^{2+}$ & 5.20 \\
\hline Clay $<2 \mu$ & 3.05 & $\mathrm{Mg}^{2+}$ & 4.18 \\
\hline Bulk density $\left[\mathrm{g} / \mathrm{cm}^{3}\right]$ & 1.52 & $\mathrm{~K}^{+}$ & 2.40 \\
\hline Total porosity $[\%]$ & 52.8 & $\mathrm{Na}^{+}$ & 5.20 \\
\hline \multicolumn{2}{|c|}{ Pore size distribution as $\%$ of total porosity } & \multicolumn{2}{|c|}{ Soluble anions $[\mathrm{meq} / \mathrm{l}]$ : } \\
\hline Macro (drainable) pores $(>28.8 \mu)$ & 82.98 & $\mathrm{CO}_{3}{ }^{2-}$ & 0.00 \\
\hline Micro pores $(<28.8 \mu)$ & 17.02 & $\mathrm{HCO}^{3-}$ & 1.70 \\
\hline Water Holding Capacity (WHC)* & 20.33 & $\mathrm{Cl}^{-}$ & 3.60 \\
\hline Field capacity $(\mathrm{FC})^{*}$ & 8.55 & $\mathrm{SO}_{4}^{2-}$ & 11.50 \\
\hline Wilting percentage (WP)* & 4.10 & Total $\mathrm{CaCO}_{3}[\%]$ & 0.20 \\
\hline Available moisture (FC-WP)* & 4.45 & Oroanis matter $[0 /$ & 020 \\
\hline Hydraulic conductivity $[\mathrm{cm} / \mathrm{h}]$ & 6.25 & 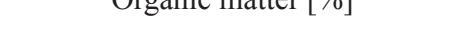 & 0.20 \\
\hline
\end{tabular}

* \% on weight basis 
form of nano particles loaded by nitrogen, bio-fertilisers and humic substances on yield, morphological, leaf and seed anatomy, chemical compositions and oil yield and constituents of caraway plants in order to reduce environmental pollution and provide safety as well as minimize economic costs that arise from the use of chemical fertilisers.

\section{MATERIAL AND METHODS}

This research was carried out at the new reclaimed area of desert located in Wadi El-Notron, Beheira Governorate (Longitude 28 ${ }^{\circ} 54^{\prime}$ E, Latitude $28^{\circ} 20 \mathrm{~N}$ and Altitude $130 \mathrm{~m}$ ) in Egypt, as an open field work, during two continual seasons (2013/14 and 2014/15), at Soil, Water and Environment Research Institute, Agriculture Research Center (A.R.C). Mechanical and chemical analyses of the reclaimed soil were performed according to Richards (1954) and Jackson (1973) and the results are shown in Table 1.

\section{Plant material, transplant and harvest dates}

The fruits of Carum carvi L. were obtained from experimental farm of Faculty of Pharmacy, Cairo University, and planted in the experimental open field on 13 October 2013 in the first season and 15

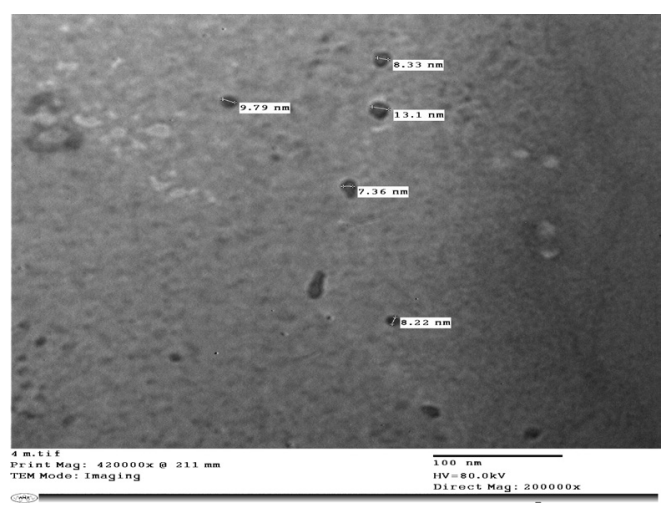

(b)

Figure 1. (a, b) Structure of nano-zeolite using scanning electron microscope (SEM)

$$
\mathrm{T} \text { a }
$$

Chemical composition of zeolite before loaded by $\mathrm{N}$

\begin{tabular}{|c|c|c|c|c|c|c|c|c|c|c|c|c|c|}
\hline \multirow{2}{*}{$\begin{array}{l}\text { Chemical } \\
\text { composition } \\
{[\%]}\end{array}$} & $\mathrm{SiO}_{2}$ & $\mathrm{TiO}_{2}$ & $\mathrm{Al}_{2} \mathrm{O}_{3}$ & $\mathrm{Fe}_{2} \mathrm{O}_{3}$ & $\mathrm{FeO}$ & $\mathrm{MnO}$ & $\mathrm{MgO}$ & $\mathrm{CaO}$ & $\mathrm{Na}_{2} \mathrm{O}$ & $\mathrm{K}_{2} \mathrm{O}$ & $\mathrm{SrO}$ & $\mathrm{P}_{2} \mathrm{O}_{3}$ & $\begin{array}{l}\text { Loss on } \\
\text { ignition }\end{array}$ \\
\hline & 45.50 & 2.81 & 13.30 & 5.40 & 8.31 & 0.51 & 6.30 & 9.52 & 2.83 & 0.87 & 0.22 & 0.67 & 3.76 \\
\hline \multirow{2}{*}{$\begin{array}{l}\text { Trace } \\
\text { elements } \\
\text { [ppm] }\end{array}$} & $\mathrm{Ba}$ & $\mathrm{Co}$ & $\mathrm{Cr}$ & $\mathrm{Se}$ & $\mathrm{Cu}$ & $\mathrm{Zn}$ & $\mathrm{Zr}$ & $\mathrm{Nb}$ & $\mathrm{Ni}$ & $\mathrm{Rb}$ & Y & - & - \\
\hline & 10 & 1.2 & 35 & 0.8 & 19 & 64 & 257 & 13 & 55 & 15 & 22 & - & - \\
\hline
\end{tabular}

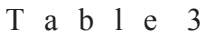

Chemical composition of nano zeolite after loaded by $\mathrm{N}$

\begin{tabular}{|c|c|c|c|c|c|c|c|c|c|c|c|c|c|}
\hline \multirow{2}{*}{$\begin{array}{l}\text { Chemical } \\
\text { composition } \\
{[\%]}\end{array}$} & $\mathrm{SiO}_{2}$ & $\mathrm{TiO}_{2}$ & $\mathrm{Al}_{2} \mathrm{O}_{3}$ & $\mathrm{Fe}_{2} \mathrm{O}_{3}$ & $\mathrm{FeO}$ & $\mathrm{MnO}$ & $\mathrm{MgO}$ & $\mathrm{CaO}$ & $\mathrm{Na}_{2} \mathrm{O}$ & $\mathrm{K}_{2} \mathrm{O}$ & $\mathrm{SrO}$ & $\mathrm{P}_{2} \mathrm{O}_{3}$ & $\mathrm{~N}$ \\
\hline & 45.50 & 2.81 & 13.30 & 5.40 & 8.31 & 0.51 & 6.30 & 9.52 & 2.83 & 0.87 & 0.22 & 0.67 & 2.70 \\
\hline \multirow{2}{*}{$\begin{array}{l}\text { Trace } \\
\text { elements } \\
{[\mathrm{ppm}]}\end{array}$} & $\mathrm{Ba}$ & $\mathrm{Co}$ & $\mathrm{Cr}$ & $\mathrm{Se}$ & $\mathrm{Cu}$ & $\mathrm{Zn}$ & $\mathrm{Zr}$ & $\mathrm{Nb}$ & $\mathrm{Ni}$ & $\mathrm{Rb}$ & $\mathrm{Y}$ & - & - \\
\hline & 10 & 1.2 & 35 & 0.8 & 19 & 64 & 257 & 13 & 55 & 15 & 22 & - & - \\
\hline
\end{tabular}


October 2014 in the second season, with a distance of $60 \mathrm{~cm}$ among rows, with a $40 \mathrm{~cm}$ spacing between plants in plots of $6 \times 7 \mathrm{~m}^{2}$ under drip irrigation. The plants were harvested from 20 to 24 May 2014 for the first season and from 18 to 21 May 2015 for the second one.

\section{Land preparation}

Before planting, the soil was first mechanically ploughed and planked twice till the soil surface settled.

\section{Fertilisers added}

Chemical fertilisers in doses recommended by the Ministry of Agriculture and Land Reclamation were added at the rate of $100 \mathrm{~kg} / \mathrm{fed}$. (one Fadden equal 4,200 $\left.\mathrm{m}^{2}\right)$. Ammonium sulphate $(20.5 \% \mathrm{~N})$ was divided into two doses; the first was added after 2 weeks of planting, while the second was four weeks later. Both calcium superphosphate $(15.5 \%$ P) at the rate of $200 \mathrm{~kg} / \mathrm{fed}$. and potassium sulphate $(48 \% \mathrm{~K})$ at the rate of $25 \mathrm{~kg} / \mathrm{fed}$. were added one day before planting. Natural zeolite (Table 2) in the form of granules was obtained from Indonesia and converted into nano size according to Hassan and Mahmoud (2015), then loaded by nitrogen (Table 3 ) by soaking in ammonium sulphate $1 \mathrm{M}$ solution for 8 days ( $\mathrm{Li}$ et al. 2013) at $25^{\circ} \mathrm{C}$. Total $\mathrm{N}$ content was analysed using the Kjeldahl digestion method (Helrich 1990). The structure was characterized using scanning electron microscope (SEM) model JSM.6390LA (JEOL) analytical (Figure 1) at

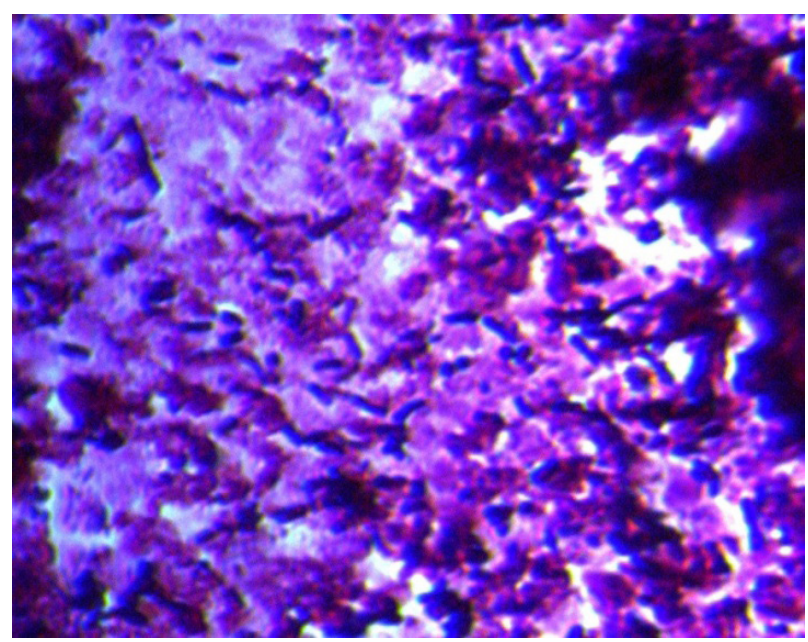

Figure 2. Bacillus megaterium and Azotobacter chroococcum mixture as shown by light microscope
Holding Company for Drinking Water and Waste Water, Greater Cairo Company for Drinking Water, Central Laboratory. Transmission electronic microscopy (TEM) was performed in TEM lab (FACURP), Faculty of Agriculture, Cairo University Research Park. Nano-zeolite-loaded nitrogen was added to the soil at the transplanting date and then as foliar at 20, 40 and 60 days after transplanting in both seasons.

\section{Biofertilisers}

Two bacterial cultures as shown by light microscope (Figure 2) containing $1 \times 110^{8} \mathrm{CFU} / \mathrm{ml}$ from Bacillus megaterium and Azotobacter chroococcum were prepared individually in the biofertiliser unit, Soils Water and Environmental Research Institute, Department of Microbiology (ARC), Giza, Egypt. Then, they were mixed well together in liquid at equal portions $(1: 1 \mathrm{v})$. Roots of seedlings were dipped into the mixture of biofertilisers for $20 \mathrm{~min}$ immediately before planting. This mixture of biofertilisers was added to plant rhizosphere through view holes already made in the soil surface for inoculation (4 holes, $20 \mathrm{~cm}$ depth) at 30,45 and 60 days after transplanting in both seasons (3 1 mixture of biofertilisers/100 1 water/fed.).

\section{Humic acids}

Humic substances obtained from Soil and Water and Environment Research Institute, Agriculture Research Center (ARC) were applied as a solution of 1 l/fed. at the transplanting date, and then 30 and

$$
\text { T a b } 1 \text { e } 4
$$

Chemical composition of humic substances

\begin{tabular}{|l|c|}
\hline Chemical composition & Value \\
\hline Humic acids & $42 \%$ \\
Fulvic acid & $48 \%$ \\
Total Nitrogen (N) & $0.5 \%$ \\
Phosphorus (P) & $0.06 \%$ \\
Potassium (K) & $0.8 \%$ \\
Calcium (Ca) & $1.0 \%$ \\
Magnesium (Mg) & $0.1 \%$ \\
Sulfur (S) & $1.3 \%$ \\
Iron (Fe) & $0.21 \%$ \\
Boron (B) & $0.01 \%$ \\
Solubility in water & $83 \%$ \\
Colour of aqueous solution & Medium brown \\
Electrical conductivity (EC) [mS/cm] & 3.140 \\
pH & 6.92 \\
\hline
\end{tabular}


60 days respectively from planting as a soil drench per season. All agricultural practices were followed as recommended during both seasons. Chemical composition of humic substances are presented in Table 4.

\section{Leaf and seed anatomy}

The specimens were taken from the leaves at the end of vegetative growth and seeds at harvest and then fixed in formalin-acetic acid alcohol (FAA) using $70 \%$ ethanol. The specimens were gradually dehydrated in a tert-butyl alcohol (TBA) series (Johansen 1940) and embedded in paraffin wax (m.p. $56^{\circ} \mathrm{C}$ ). Sections were cut on a rotary microtome at a thickness of 8-10 $\mu \mathrm{m}$ (Model RM2245, Leica Microsystems). Paraffin was removed with xylol and slides were stained with safranin FCF methanol and fast green and then mounted in Canada balsam (Johansen 1940). The selected sections were examined and photographed using a light microscope (Model BX51; Olympus Optical).

\section{Treatments}

- NPK fertilisers (recommended doses) as control

- Humic substances;

- Nano-zeolite-loaded nitrogen;

- Biofertilisers;

- Humic substances + Nano-zeolite + Biofertilisers (HNB) as shown in Figure 3.

\section{Data recorded}

\section{Growth parameters}

Plant height $[\mathrm{cm}]$, number of branches/plant, number of umbles/plant, plant fresh weight $[\mathrm{g}]$,

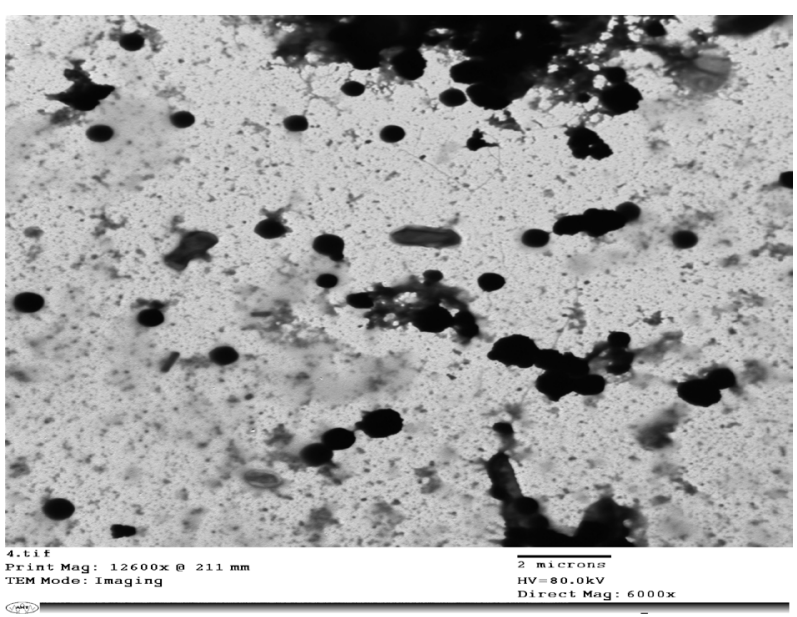

Figure 3. TEM of mixture Humic substances + Nanozeolite + Biofertilisers (HNB treatment) plant dry weight [g], weight of umbles/plant [g], fruit weight/plant $[\mathrm{g}]$, fruit yield/ha [t].

\section{Chemical Analysis}

The chemical constituents such as $\mathrm{N}, \mathrm{P}, \mathrm{K}, \mathrm{Ca}$, $\mathrm{Mg}, \mathrm{Fe}$ and $\mathrm{Zn}$ were measured in the dry material. The wet digestion of $0.2 \mathrm{~g}$ plant material with sulphuric and perchloric acids was carried out on herbs by adding concentrated sulphuric acid $(5 \mathrm{ml})$ to the samples and the mixture was heated for 10 min. Then $0.5 \mathrm{ml}$ perchloric acid was added and heating continued till a clear solution was obtained. The digested solution was quantitatively transferred to a $100 \mathrm{ml}$ volumetric flask using deionized water as reported by Piper (1950).

The total nitrogen content of the dried leaves was determined by using the modified micro-Kjeldahl method as described by Helrich (1990).

Phosphorus was determined calorimetrically by using the chlorostannous molybdophosphoric blue colour method in sulphuric acid according to Jackson (1973).

Potassium concentrations were determined by using the flame photometer apparatus (CORNING M 410, Germany).

Vitamin $\mathrm{C}$ as ascorbic acid [mg] was determined in seeds and estimated per $100 \mathrm{ml}$ fresh weight, according to Helrich (1990) method.

Concentrations of $\mathrm{Ca}, \mathrm{Mg}, \mathrm{Fe}$ and $\mathrm{Zn}$ in plant samples were determined using atomic absorption spectrophotometer with air-acetylene and fuel (Pye Unicam, model SP-1900, US).

\section{Plant pigments}

Total chlorophyll and carotenoid content were measured by spectrophotometer and calculated according to the equation described by Moran (1982).

Total carbohydrates in plant herbs were determined by phosphomolybdic acid method according to Helrich (1990).

Total phenolic contents of the extracts were determined spectrophotometrically according to the Folin-Ciocalteu colorimetric method (Singleton \& Rossi 1965).

Total flavonoid was determined using the method of Meda et al. (2005).

Total fatty acids in seeds were converted into their methyl esters using 3\% sodium methylate in methanol according to the method described by Cecchi et al. (1985). 


\section{HPLC analysis of thiamine}

Assays of thiamine in caraway seeds were carried out using a method described by Rapala-Kozik et al. (2008).

\section{Endogenous phytohormones}

The analysis was performed according to Fales et al. (1973) for the determination of gibberellic acid (GA), abscisic acid (ABA) and indole-acetic acid (IAA). The quantification of the endogenous phytohormones was carried out with Ati-Unicum gasliquid chromatography, 610 Series, equipped with flame ionization detector according to the method described by Vogel (1975).

\section{Essential oil isolation}

Air-dried seeds ( $50 \mathrm{~g})$ were subjected to hydrodistillation for $90 \mathrm{~min}$ (time fixed after a kinetic survey during 30,60, 90 and $120 \mathrm{~min}$ ). The optimal yield was obtained at $90 \mathrm{~min}$.

\section{Gas chromatography-mass spectrometry}

The GC-MS analyses were performed on a gas chromatograph HP 6890 (II) interfaced with a HP 5973 mass spectrometer (Agilent Technologies, Palo Alto, CA, USA) with electron impact ionization $(70 \mathrm{eV})$. An apolar HP-5MS capillary column $(60 \mathrm{~m} \times 0.25 \mathrm{~mm}, 0.25 \mathrm{~m}$ film thickness) was used.

\section{Data analysis}

The experimental design was randomized complete block design with six replicates. Data were subjected to statistical analysis using ANOVA at $5 \%$ significance level. The difference between treatments then analysed using DMRT (Duncan Multiple Range Test) at $5 \%$.

\section{Economical evaluation}

The yield components were calculated and economic analysis was performed using the following equations proposed by Sarwar et al. (2007); FAO (2000) and Mubashir et al. (2010).

Gross income $=$ yield $\times$ price

Profitable return $(\mathrm{PR})=$ gross income - total production cost

$\mathrm{PR} \%$ over control $=\mathrm{PR}-$ control treatments

Benefit cost ratio $(\mathrm{BCR})=\mathrm{PR}$ over control/total production cost

Investment factor $(\mathrm{IF})=$ gross income/total produc- tion cost

(IF) must equal or more 3

\section{RESULTS AND DISCUSSION}

\section{Growth characters}

The data representing caraway morphology (Tables 5 and 6) revealed that a combination of humic substances, nano-zeolite-loaded nitrogen and biofertiliser (HNB) treatment had pivotal effect on plants. They significantly increased all growth parameters of caraway plants in comparison with either control (plants receiving recommended dose of NPK fertilisers) or all=other treatments in both growing seasons. These increases were $(67 \%$ and $68 \%$ ) respectively in fruit yield/ha compared to that in control treatment. The results of the combined humic substance and nano-zeolite-loaded nitrogen treatments as well individual treatments were significantly higher than the results of control plants. It was clear also that the application of biofertilisers alone significantly limited the growth of caraway and its biomass production. As a result, the reduction from biofertilisers treatment was $46 \%$ and $62 \%$ compared to control in the first and second season, respectively.

Our data provide a plausible mechanism for how the combination of humic substances, nano-zeolite-loaded nitrogen and biofertilisers (HNB) together boost all growth parameters as compared to control. The beneficial effects of these treatments on caraway plant are due to nutrient availability and improvement of soil's physical, chemical and biological properties as evident by higher water retention, decreased soil $\mathrm{pH}$, higher $\mathrm{CEC}$, increased soil organic matter in addition to availability of elements to be absorbed by plant roots. Given the significant role of nanoscale (nano-zeolite-loaded nitrogen), the authors confirmed that nanoparticles interact with plants, causing many morphological and physiological changes, depending on their properties and chemical composition, size and surface covering (Khodakovskaya et al. 2012). Other suggested positive effects on plant growth and development and their impact on plants depend on the composition, concentration, size and physical and chemical 
properties as well as plant species (Ma et al. 2010). More evidence of positive effects was reported on kale (Brassica alboglabra Bailey). Li et al. (2013) indicated that the application of ammonium- and potassium-loaded zeolite resulted in an increase in the total harvest weight over control plants. Ranjbar et al. (2004) and Bernardi et al. (2008) reported on similar treatments on tobacco and oat, respectively and found that zeolite application increased leaf area, plant height and stem diameter relative to the control without zeolite. Additionally, Hassan et al. (2006) observed that rosemary plants receiving compost in combination with mixture of bio-fertilisers recorded considerable increases in growth characteristics represented in fresh herb, dry weight and number of branches when compared to inorganic fertiliser treatment.

\section{Effect on elements content}

The highest content of both macro and micro elements resulted from the application of mixed humic substances, nano-zeolite-loaded nitrogen and biofertilisers (HNB). This increase was statistically significant with $\mathrm{N}, \mathrm{P}, \mathrm{Ca}, \mathrm{Fe}$ and $\mathrm{Zn}$ compared to control plants (Table 7) since it recorded 79\% for nitrogen, $72 \%$ and $74 \%$ for phosphorus, $83 \%$ and $76 \%$ for calcium, $52 \%$ and $54 \%$ for iron and $81 \%$ and $79 \%$ for zinc, respectively, for both first and second seasons. Also, it was noticed that the same previous treatment had recorded an increase of potassium over control in both growing seasons although this increase was not significant in the first season (91\%), but it was statistically significant $(89 \%)$ in the second one. The same result was found with magnesium as a result of HNB treatment

T a b 1 e 5

Effect of different treatments on plant height, number of branches and number of umbles of caraway plant during two seasons 2013 and 2014

\begin{tabular}{|l|c|c|c|c|c|c|}
\hline \multirow{2}{*}{ Treatment } & \multicolumn{2}{|c|}{ Plant height $[\mathrm{cm}]$} & \multicolumn{2}{|c|}{ No. of branches/plant } & \multicolumn{2}{c|}{ No. of umbles/plant } \\
\cline { 2 - 7 } & $\mathrm{F}$ & $\mathrm{S}$ & $\mathrm{F}$ & $\mathrm{S}$ & $\mathrm{F}$ & $\mathrm{S}$ \\
\hline NPK & $91.7^{\mathrm{b}}$ & $94.0^{\mathrm{b}}$ & $8.56^{\mathrm{b}}$ & $8.95^{\mathrm{b}}$ & $31.48^{\mathrm{b}}$ & $35.23^{\mathrm{b}}$ \\
Humic substances (H) & $80.3^{\mathrm{c}}$ & $83.6^{\mathrm{c}}$ & $8.07^{\mathrm{b}}$ & $8.84^{\mathrm{b}}$ & $28.72^{\mathrm{b}}$ & $30.21^{\mathrm{b}}$ \\
Nano Zeolite (N) & $82.5^{\mathrm{c}}$ & $83.2^{\mathrm{c}}$ & $7.89^{\mathrm{b}}$ & $8.80^{\mathrm{b}}$ & $30.22^{\mathrm{b}}$ & $34.55^{\mathrm{b}}$ \\
Biofertilisers (B) & $66.8^{\mathrm{d}}$ & $69.3^{\mathrm{d}}$ & $6.44^{\mathrm{c}}$ & $7.36^{\mathrm{b}}$ & $22.40^{\mathrm{c}}$ & $25.36^{\mathrm{c}}$ \\
HNB & $111.6^{\mathrm{a}}$ & $115.7^{\mathrm{a}}$ & $10.89^{\mathrm{a}}$ & $11.12^{\mathrm{a}}$ & $40.65^{\mathrm{a}}$ & $49.28^{\mathrm{a}}$ \\
\hline
\end{tabular}

Means with the same letters in a column are not significantly different by DMRT 5\%

$\mathrm{F}$ - first season; $\mathrm{S}$ - second season

$\mathrm{T}$ a

Effect of different treatments on plant fresh weight, plant dry weight, weight of umbles, fruit weight and fruit yield of caraway plant during two seasons 2013 and 2014

\begin{tabular}{|l|c|c|c|c|c|c|c|c|c|c|}
\hline \multirow{2}{*}{ Treatment } & \multicolumn{2}{|c|}{$\begin{array}{c}\text { Plant fresh } \\
\text { weight [g] }\end{array}$} & \multicolumn{2}{c|}{$\begin{array}{c}\text { Plant dry weight } \\
{[\mathrm{g}]}\end{array}$} & \multicolumn{2}{c|}{$\begin{array}{c}\text { Weight of } \\
\text { umbles/plant [g] }\end{array}$} & \multicolumn{2}{c|}{$\begin{array}{c}\text { Fruit weight/ } \\
\text { plant [g] }\end{array}$} & \multicolumn{2}{c|}{ Fruit yield [t/ha] } \\
\cline { 2 - 12 } & $\mathrm{F}$ & $\mathrm{S}$ & $\mathrm{F}$ & $\mathrm{S}$ & $\mathrm{F}$ & $\mathrm{S}$ & $\mathrm{F}$ & $\mathrm{S}$ & $\mathrm{F}$ & $\mathrm{S}$ \\
\hline NPK & $219.6^{\mathrm{b}}$ & $225.5^{\mathrm{b}}$ & $51.42^{\mathrm{b}}$ & $55.61^{\mathrm{b}}$ & $96.24^{\mathrm{b}}$ & $100.3^{\mathrm{b}}$ & $60.54^{\mathrm{b}}$ & $65.47^{\mathrm{b}}$ & $2.61^{\mathrm{b}}$ & $2.51^{\mathrm{b}}$ \\
Humic substances (H) & $200.3^{\mathrm{c}}$ & $213.3^{\mathrm{c}}$ & $44.81^{\mathrm{c}}$ & $48.89^{\mathrm{b}}$ & $89.17^{\mathrm{c}}$ & $93.51^{\mathrm{c}}$ & $54.87^{\mathrm{c}}$ & $61.55^{\mathrm{b}}$ & $2.16^{\mathrm{b}}$ & $2.41^{\mathrm{b}}$ \\
Nano Zeolite (N) & $215.5^{\mathrm{b}}$ & $221.0^{\mathrm{b}}$ & $48.56^{\mathrm{b}}$ & $50.77^{\mathrm{b}}$ & $91.50^{\mathrm{c}}$ & $98.10^{\mathrm{b}}$ & $57.21^{\mathrm{c}}$ & $63.12^{\mathrm{b}}$ & $2.25^{\mathrm{b}}$ & $2.48^{\mathrm{b}}$ \\
Biofertilisers (B) & $185.7^{\mathrm{d}}$ & $190.3^{\mathrm{d}}$ & $41.33^{\mathrm{c}}$ & $45.27^{\mathrm{c}}$ & $72.46^{\mathrm{d}}$ & $79.54^{\mathrm{d}}$ & $38.91^{\mathrm{d}}$ & $45.71^{\mathrm{c}}$ & $1.20^{\mathrm{c}}$ & $1.56^{\mathrm{c}}$ \\
HNB & $286.6^{\mathrm{a}}$ & $300.2^{\mathrm{a}}$ & $68.58^{\mathrm{a}}$ & $70.97^{\mathrm{a}}$ & $112.83^{\mathrm{a}}$ & $120.60^{\mathrm{a}}$ & $86.31^{\mathrm{a}}$ & $90.64^{\mathrm{a}}$ & $3.40^{\mathrm{a}}$ & $3.67^{\mathrm{a}}$ \\
\hline
\end{tabular}

Means with the same letters in a column are not significantly different by DMRT $5 \%$

$\mathrm{F}$ - first season; $\mathrm{S}$ - second season 
where its increase over control, although not significant, was recorded at $90 \%$ in the first season while in the second season, it gave significant increases (88\%). Many researches confirmed the important role of zeolite, which has specific ion-exchange, adsorption, catalytic properties, and promotes keeping nutrients in the plough horizon, which makes it possible to reduce their losses in soil from washing out and to obtain beneficial results as an after-effect (Ryakhovskaya \& Gainatulina 2009), besides producing long-term soil improvements as well as slow release of the fertiliser in the form of nano nitrogen. Zeolites can also act as water moderators, in which they will adsorb up to $55 \%$ of their weight in water and slowly release it upon plant demand (Monnier \& Dupont 1983). This has a great effect in desert reclamation processes particularly in arid and semiarid areas.

Moreover, zeolite containing macro and micronutrients, loaded with nano nitrogen and its channels, provide large surface areas on which chemical reactions can take place by making nutrients more effective by enabling ammonium nitrate, potassium, magnesium and calcium as well as trace elements for slow release as needed (Kallo et al. 1986). Along with humic substances and biofertilisers acting as excellent sources of nutrients, they also improve physical and chemical properties of soil, decrease soil $\mathrm{pH}$, which leads to solubilization of nutrients and increases its availability, minimizes the loss of nutrients by leaching and stimulates increase of population and activities of micro-organisms in the soil (Bernardi et al. 2008).
Effect on plant pigments, total carbohydrates, ascorbic acid and thiamine

The combination of humic substances, nano-zeolite-loaded nitrogen and biofertilisers (HNB) increased total chlorophyll and carotenoids (Table 8). Whereas total chlorophyll significantly increased by $72 \%$ in both seasons over control, carotenoids content also increased significantly (85\%) in the first season compared with control. This increase continued in the second season, but was not significant. The elevated amount in total chlorophyll and carotenoids content may be due to the beneficial effects of humic acids and positive role of zeolite in the presence of biofertilisers, which give excellent combination for more available nutrients and overcoming most macro and micro nutrient deficiency, particularly of nitrogen, iron and zinc, in sandy soil, which is efficient in the photosynthesis process. They also build high capacity of the plants for building metabolites, which in turn contributes much to the increase of nutrient uptake. Our results are in agreement with those obtained by Al-Qadsia (2004) on Ocimum basilicum and Ranjbar et al. (2004) on tobacco.

As far as total carbohydrates are concerned, data in Table 8 illustrated that the increase in total carbohydrates as a consequence of HNB application was significant $(84 \%)$ in the first season compared to control plants, while the increase over control treatment in the second season was insignificant. On the other hand, during both seasons, application of biofertilisers alone led to significantly lower carbohydrate content ( $80 \%$ and $84 \%$, respectively)

T

Effect of different treatments on nitrogen, phosphor, potassium, calcium, magnesium, iron and zinc in the herb of caraway plant during two seasons 2013 and 2014

\begin{tabular}{|c|c|c|c|c|c|c|c|c|c|c|c|c|c|c|}
\hline \multirow{2}{*}{ Treatment } & \multicolumn{2}{|c|}{$\mathrm{N}[\%]$} & \multicolumn{2}{|c|}{$\mathrm{P}[\%]$} & \multicolumn{2}{|c|}{$\mathrm{K}[\%]$} & \multicolumn{2}{|c|}{$\mathrm{Ca}[\%]$} & \multicolumn{2}{|c|}{$\operatorname{Mg}[\%]$} & \multicolumn{2}{|c|}{$\mathrm{Fe}[\mathrm{ppm}]$} & \multicolumn{2}{|c|}{$\mathrm{Zn}[\mathrm{ppm}]$} \\
\hline & $\mathrm{F}$ & $\mathrm{S}$ & $\mathrm{F}$ & $\mathrm{S}$ & $\mathrm{F}$ & $\mathrm{S}$ & $\mathrm{F}$ & $\mathrm{S}$ & $\mathrm{F}$ & $\mathrm{S}$ & $\mathrm{F}$ & $\mathrm{S}$ & $\mathrm{F}$ & $\mathrm{S}$ \\
\hline NPK & $2.53^{b}$ & $2.71^{\mathrm{b}}$ & $.26^{\mathrm{b}}$ & $28^{\mathrm{b}}$ & $3.40^{\mathrm{a}}$ & $3.70^{b}$ & $.53^{\mathrm{c}}$ & $1.55^{\mathrm{c}}$ & $.35^{\mathrm{a}}$ & $0.37^{\mathrm{b}}$ & $170^{\mathrm{c}}$ & $183^{\mathrm{c}}$ & $49.3^{\mathrm{c}}$ & $53.5^{b}$ \\
\hline Humic substances $(\mathrm{H})$ & $1.81^{\mathrm{c}}$ & $2.08^{\mathrm{c}}$ & $0.30^{\mathrm{b}}$ & $0.33^{\mathrm{a}}$ & $3.20^{\mathrm{a}}$ & $3.50^{\mathrm{b}}$ & $1.58^{\mathrm{c}}$ & $1.80^{\mathrm{b}}$ & $0.37^{\mathrm{a}}$ & $0.36^{\mathrm{b}}$ & $191^{\mathrm{b}}$ & $198^{\mathrm{b}}$ & $52.7^{\mathrm{b}}$ & $55.6^{\mathrm{b}}$ \\
\hline Nan & $2.31^{\mathrm{b}}$ & $2.55^{\mathrm{b}}$ & $0.35^{\mathrm{a}}$ & $0.36^{\mathrm{a}}$ & $3.50^{\mathrm{a}}$ & $4.05^{\mathrm{a}}$ & $1.71^{\mathrm{b}}$ & $1.61^{\mathrm{c}}$ & $0.33^{\mathrm{a}}$ & $0.35^{\mathrm{b}}$ & $200^{\mathrm{b}}$ & $215^{\mathrm{b}}$ & $56.8^{\mathrm{b}}$ & $60.0^{\mathrm{a}}$ \\
\hline Biofertilisers (B) & $1.86^{\mathrm{c}}$ & $2.16^{\mathrm{c}}$ & $0.21^{\mathrm{c}}$ & $0.24^{\mathrm{b}}$ & $2.70^{\mathrm{b}}$ & $3.03^{\mathrm{b}}$ & $1.21^{\mathrm{d}}$ & $1.37^{\mathrm{d}}$ & $0.29^{\mathrm{b}}$ & $0.32^{\mathrm{c}}$ & $155^{\mathrm{d}}$ & $169^{d}$ & $42.5^{\mathrm{d}}$ & $48.7^{\mathrm{c}}$ \\
\hline HNB & $3.21^{\mathrm{a}}$ & $3.44^{\mathrm{a}}$ & $0.36^{\mathrm{a}}$ & $0.38^{\mathrm{a}}$ & $3.73^{\mathrm{a}}$ & $4.18^{\mathrm{a}}$ & $1.83^{\mathrm{a}}$ & $2.03^{\mathrm{a}}$ & $0.39^{\mathrm{a}}$ & $0.42^{\mathrm{a}}$ & $324^{\mathrm{a}}$ & $341^{\mathrm{a}}$ & $60.2^{\mathrm{a}}$ & $67.4^{\mathrm{a}}$ \\
\hline
\end{tabular}

Means with the same letters in a column are not significantly different by DMRT $5 \%$

F - first season; S - second season 
in comparison with control (NPK). The increase in total carbohydrates may be due to the increase of photosynthesis as a result of increase in photosynthetic pigment content in leaves. HNB appears to be a source of a number of essential elements that may play an important role in plant metabolism, notably the most significant function would appear to involve carbohydrate metabolism and photosynthesis (Tisdale \& Nelson 1975). Similar results were found by Jin et al. (2008) on acer plant. Interestingly, the same trend was obtained with ascorbic acid where in the first season, HNB treatment significantly increased the amount of ascorbic acid (80.5\%) over control. Also in the second season, there was an increase recorded for aforesaid treatment compared to control in spite of that increase being insignificant.
Matching results were obtained by Soliman and Mahmoud (2013) on Adansonia digitata L.

During both seasons, there was significant increase in thiamine, which recorded increase of $92.5 \%$ and $91 \%$, respectively, over control as a result of HNB application (Table 8). Thiamine content recorded insignificant results from other treatments represented in humic substances, nano-zeolite and biofertilisers individually in comparison with the results of control treatment in both seasons. The increase in ascorbic acid and thiamine may be due to advantageous effects of the combination of humic substances, nano-zeolite and biofertilisers together resulting in more release of nutrients in an available form for plant uptake, which resulted in higher efficiency of the photosynthesis process, increasing

$\mathrm{T}$ a

Effect of different treatments on total chlorophyll content [ $\mathrm{mg} / \mathrm{g}$ fresh weight], total carbohydrates, carotenoids content, ascorbic acid and thiamine of Caraway plant during two seasons 2013 and 2014

\begin{tabular}{|l|c|c|c|c|c|c|c|c|c|c|}
\hline \multirow{2}{*}{ Treatment } & $\begin{array}{c}\text { Total chlorophyll } \\
{[\mathrm{mg} / \mathrm{g}]}\end{array}$ & \multicolumn{2}{|c|}{$\begin{array}{c}\text { Total } \\
\text { carbohydrates } \\
{[\%]}\end{array}$} & \multicolumn{2}{c|}{$\begin{array}{c}\text { Carotenoids } \\
\text { content }[\mathrm{mg} / \mathrm{g}]\end{array}$} & \multicolumn{2}{c|}{$\begin{array}{c}\text { Ascorbic } \\
\text { acid/100 g seed }\end{array}$} & \multicolumn{2}{c|}{$\begin{array}{c}\text { Thiamine } / 100 \mathrm{~g} \\
\text { seed }\end{array}$} \\
\cline { 2 - 12 } & $\mathrm{F}$ & $\mathrm{S}$ & $\mathrm{F}$ & $\mathrm{S}$ & $\mathrm{F}$ & $\mathrm{S}$ & $\mathrm{F}$ & $\mathrm{S}$ & $\mathrm{F}$ & $\mathrm{S}$ \\
\hline NPK & $2.29^{\mathrm{b}}$ & $2.32^{\mathrm{b}}$ & $27.41^{\mathrm{b}}$ & $30.72^{\mathrm{a}}$ & $0.52^{\mathrm{b}}$ & $0.59^{\mathrm{a}}$ & $17.22^{\mathrm{b}}$ & $17.86^{\mathrm{a}}$ & $0.371^{\mathrm{b}}$ & $0.384^{\mathrm{b}}$ \\
Humic substances (H) & $1.97^{\mathrm{c}}$ & $2.28^{\mathrm{b}}$ & $25.31^{\mathrm{b}}$ & $28.44^{\mathrm{a}}$ & $0.43^{\mathrm{c}}$ & $0.49^{\mathrm{b}}$ & $17.37^{\mathrm{b}}$ & $19.13^{\mathrm{a}}$ & $0.381^{\mathrm{b}}$ & $0.388^{\mathrm{b}}$ \\
Nano Zeolite (N) & $2.3^{\mathrm{b}}$ & $2.54^{\mathrm{b}}$ & $27.39^{\mathrm{b}}$ & $31.62^{\mathrm{a}}$ & $0.55^{\mathrm{b}}$ & $0.58^{\mathrm{a}}$ & $18.09^{\mathrm{b}}$ & $18.67^{\mathrm{a}}$ & $0.387^{\mathrm{b}}$ & $0.391^{\mathrm{b}}$ \\
Biofertilisers (B) & $1.73^{\mathrm{c}}$ & $2.01^{\mathrm{c}}$ & $21.89^{\mathrm{c}}$ & $25.82^{\mathrm{b}}$ & $0.40^{\mathrm{c}}$ & $0.46^{\mathrm{b}}$ & $14.98^{\mathrm{c}}$ & $15.12^{\mathrm{b}}$ & $0.359^{\mathrm{b}}$ & $0.366^{\mathrm{b}}$ \\
HNB & $3.17^{\mathrm{a}}$ & $3.19^{\mathrm{a}}$ & $32.49^{\mathrm{a}}$ & $35.11^{\mathrm{a}}$ & $0.61^{\mathrm{a}}$ & $0.65^{\mathrm{a}}$ & $21.38^{\mathrm{a}}$ & $21.42^{\mathrm{a}}$ & $0.401^{\mathrm{a}}$ & $0.422^{\mathrm{a}}$ \\
\hline
\end{tabular}

Means with the same letters in a column are not significantly different by DMRT $5 \%$

F - first season; $\mathrm{S}$ - second season

T a b 1 e 9

Effect of different treatments on total phenols, total flavonoids and total fatty acids of caraway plant during two seasons 2013 and 2014

\begin{tabular}{|l|c|c|c|c|c|c|}
\hline \multirow{2}{*}{ Treatment } & \multicolumn{2}{|c|}{$\begin{array}{c}\text { Total phenols } \\
{[\mu \mathrm{g} \mathrm{CE} / \mathrm{g}]}\end{array}$} & \multicolumn{2}{c|}{$\begin{array}{c}\text { Total flavonoids } \\
{[\mu \mathrm{g} \text { CE/g] }}\end{array}$} & \multicolumn{2}{c|}{$\begin{array}{c}\text { Total fatty acids } \\
{[\mathrm{mg} / \mathrm{g} \text { DW seed }]}\end{array}$} \\
\cline { 2 - 7 } & $\mathrm{F}$ & $\mathrm{S}$ & $\mathrm{F}$ & $\mathrm{S}$ & $\mathrm{F}$ & $\mathrm{S}$ \\
\hline NPK & $8.69^{\mathrm{b}}$ & $8.65^{\mathrm{b}}$ & $42.11^{\mathrm{a}}$ & $45.27^{\mathrm{a}}$ & $55.42^{\mathrm{c}}$ & $60.33^{\mathrm{b}}$ \\
Humic substances (H) & $8.72^{\mathrm{b}}$ & $8.77^{\mathrm{b}}$ & $40.32^{\mathrm{a}}$ & $41.53^{\mathrm{b}}$ & $52.28^{\mathrm{c}}$ & $56.88^{\mathrm{c}}$ \\
Nano Zeolite (N) & $8.78^{\mathrm{b}}$ & $8.81^{\mathrm{b}}$ & $41.21^{\mathrm{a}}$ & $44.36^{\mathrm{a}}$ & $60.12^{\mathrm{b}}$ & $58.43^{\mathrm{c}}$ \\
Biofertilisers (B) & $9.15^{\mathrm{a}}$ & $9.33^{\mathrm{a}}$ & $37.32^{\mathrm{b}}$ & $38.89^{\mathrm{b}}$ & $39.46^{\mathrm{d}}$ & $35.22^{\mathrm{d}}$ \\
HNB & $8.55^{\mathrm{b}}$ & $8.70^{\mathrm{b}}$ & $45.48^{\mathrm{a}}$ & $47.51^{\mathrm{a}}$ & $68.95^{\mathrm{a}}$ & $69.71^{\mathrm{a}}$ \\
\hline
\end{tabular}

Means with the same letters in a column are not significantly different by DMRT $5 \%$

F - first season; $\mathrm{S}$ - second season 
amino acid and vitamin synthesis in plant tissue. These results are in agreement with those obtained from Leclerc et al. (1991) on carrot and celery root and Soliman and Mahmoud (2013) on Adansonia digitata $\mathrm{L}$.

Effect on total phenolics, total flavonoids and total fatty acids

Previous researches indicated that fertilisation type had an influence on the phyto-nutritional quality of crops. Inorganic fertilisers are believed to reduce the antioxidant levels while organic fertilisers were proven to enhance the antioxidant content in plants (Dumas et al. 2003). Our data shown in Table 9 revealed that biofertiliser treatment significantly increased total phenolics in both seasons $(94 \%$ and $92.7 \%$ ) compared either with control and all other treatments including mixed HNB treatment. Meanwhile there were insignificant differences re- corded during both seasons with humic substances, nano zeolite and mixed HNB treatments compared to control plants. On the other hand, total flavonoids were found to be significantly having lowest content ( $88.6 \%$ and $86 \%$, respectively) in the first and second seasons with biofertiliser treatment compared with control. Mixed HNB treatment gave the highest content of flavonoids against control and all other treatments in both seasons, although that increase was insignificant. There was insignificant difference in total flavonoids resulting from humic substances, nano zeolite and mixed HNB treatments in comparison with control, particularly in the first season. The results obtained with regard to total phenolics and total flavonoids are in parallel with those obtained by Omar et al. (2012) on cassava tubers and Asami et al. (2003) on dried marion berry, strawberry and corn.
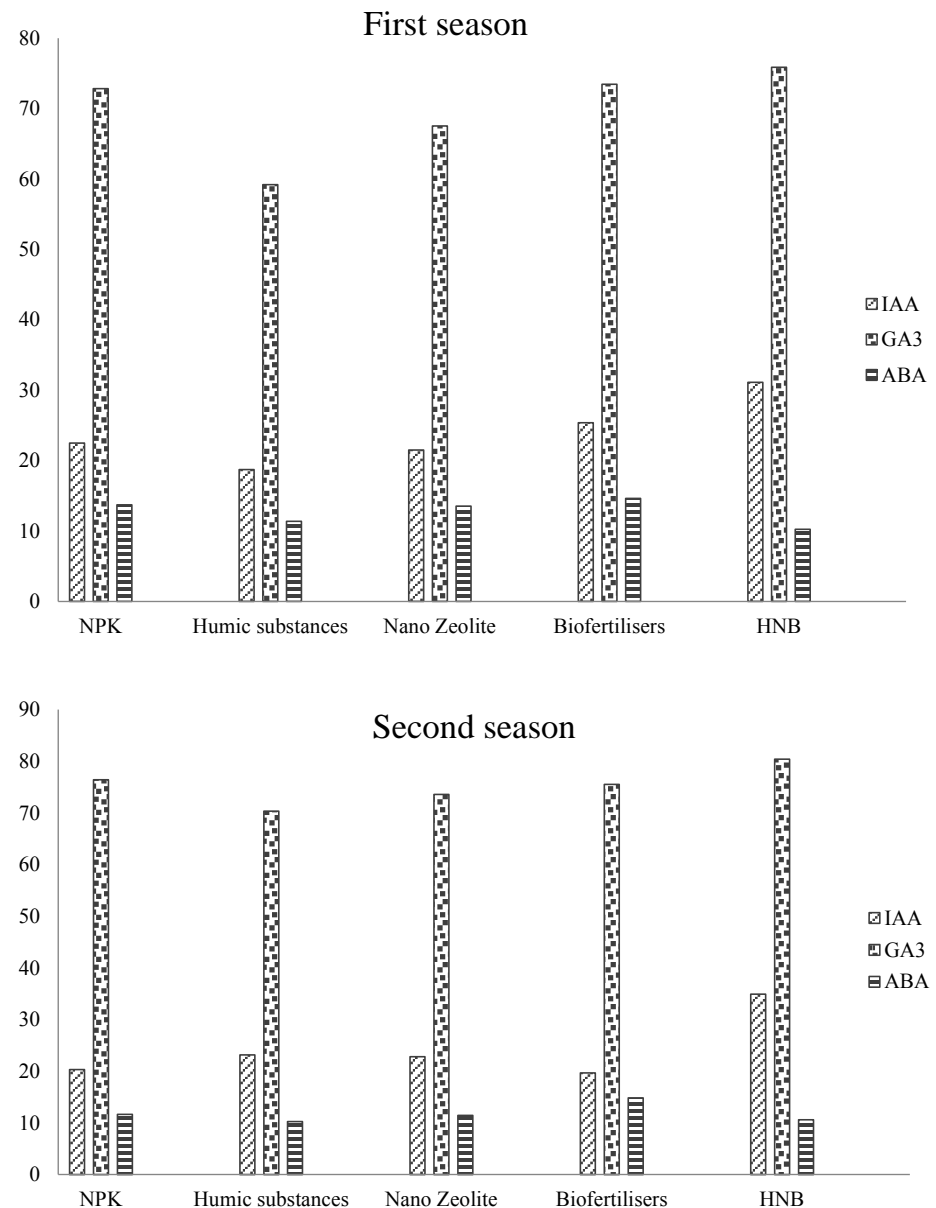

Figure 4. Effect of different treatments on endogenous hormones $[\mu \mathrm{g} / \mathrm{g}$ FW] caraway plant during two seasons 2013 and 2014 
In this connection, data in Table 9 show that, in both first and second seasons, total fatty acids significantly increased ( $80 \%$ and $87 \%$, respectively) as a result of HNB treatment compared with control. Also it was noteworthy that mixed HNB treatment significantly had the upper hand in total fatty acid content compared to all other treatments during both seasons. On the contrary, the lowest total fatty acids resulted from the application of biofertilisers alone either in first or second season in comparison to control and all other treatments. Our previous data are in conformity with the results obtained by Sinkovič and Žnidarčič (2016) on Radicchio plant. The different influences of humic substances, nano zeolite and biofertilisers mixed (HNB) on total phenolics, total flavonoids and total fatty acids and physiological activities could be due to the power of releasing and chelating available nutrients for plant uptake along

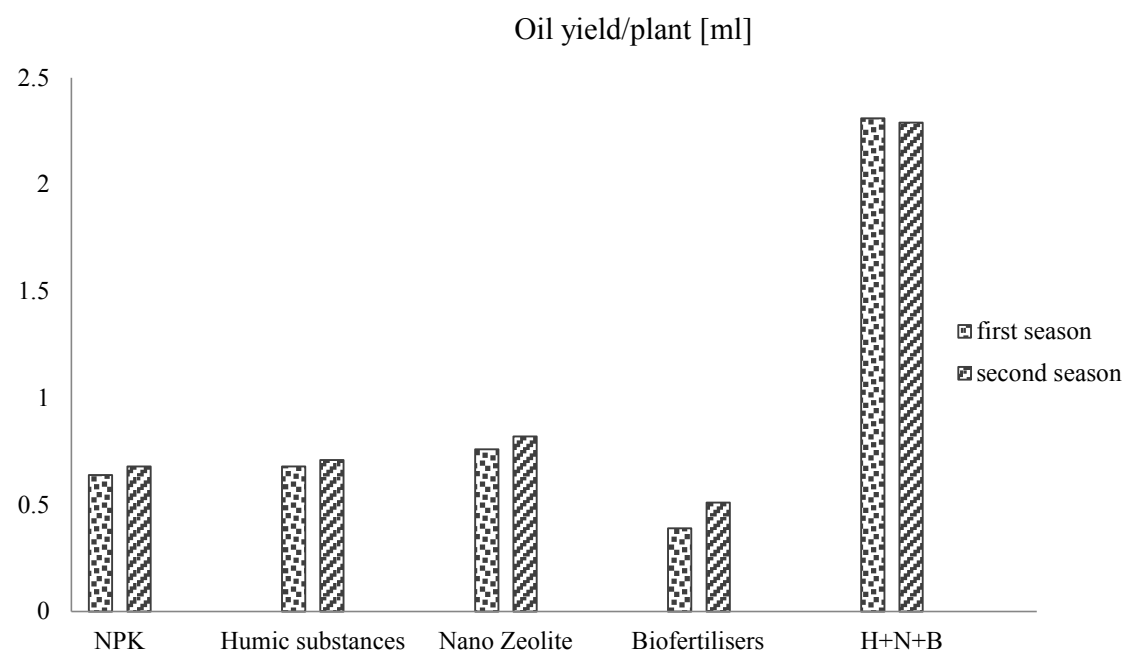

Figure 5. Effect of different treatments on essential oil in the herb of caraway plant as oil yield per plant during two seasons 2013 and 2014

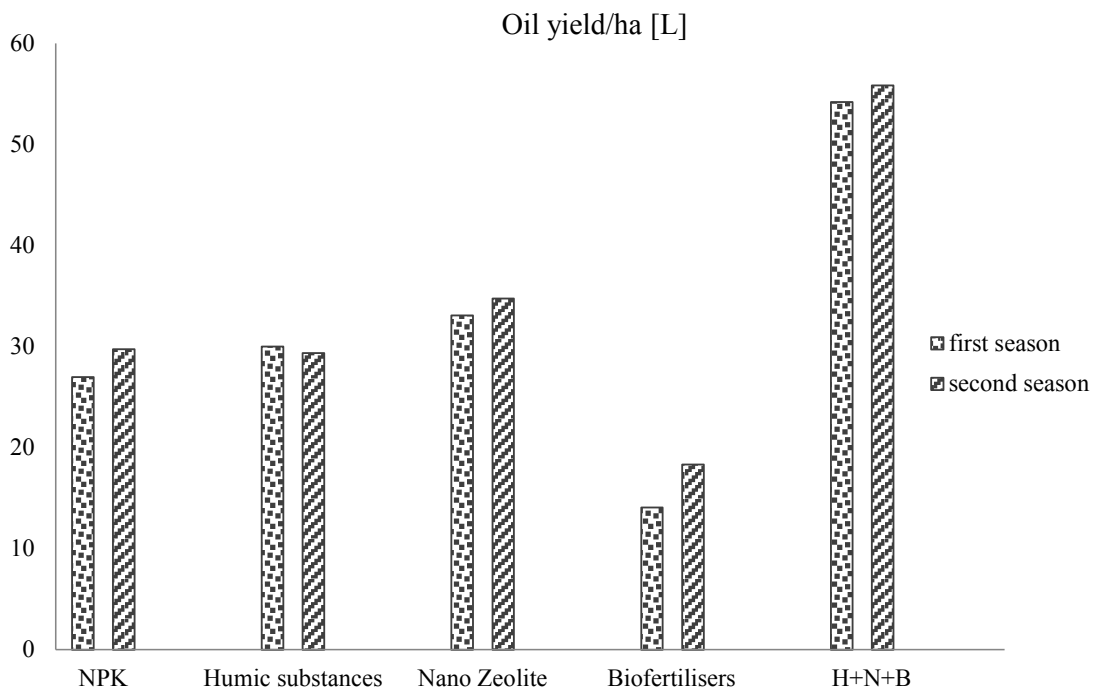

Figure 6. Effect of different treatments on essential oil in the herb of caraway plant as oil yield per hectare during two seasons 2013 and 2014 
with their impacts on physiochemical and biological properties, which also enable efficient use of biofertilisers and organic fertilisers. Generally seed composition constituents were reported to be genetically controlled (Simpson \& Wilcox 1983). However, seed composition has also shown to be affected by environment (Dardanelli et al. 2006), genotype, maturity, diseases, planting date (Bellaloui et al. 2011), temperature (Dardanelli et al. 2006), drought (Bellaloui et al. 2012), nutrients in soil and seed (Kravchenko \& Bullock 2002).

\section{Effect on phytohormones}

The results of hormonal analysis as evident from levels of indole-3-acetic acid (IAA), gibberellic acid $\left(\mathrm{GA}_{3}\right)$ and abscisic acid (ABA) in caraway herb are affected by different treatments, as displayed in Figure 4. The increase of growth parameter was associated with elevated levels of growth promoters (IAA, $\mathrm{GA}_{3}$ ) and low level of ABA. Hence it was found that mixed (HNB) treatment significantly gave the highest content of IAA, particularly in comparison to control ( $72 \%$ and $58 \%$, respectively) in both seasons. As for $\mathrm{GA}_{3}$, it was clear that mixed (HNB) treatment resulted in an increase over control in $\mathrm{GA}_{3}$ content, although this increase was insig- nificant but, in the second season (HNB), the treatment resulted in significant increases compared with all other treatments and mainly (95\%) over control. Concerning ABA content, in the first season, both humic substances and mixed HNB treatments significantly resulted in the lowest $\mathrm{ABA}$ content $(83 \%$ and $75 \%$, respectively) compared with control plants. In contrast, in the second season, it was unequivocal that the highest ABA content significantly resulted from biofertiliser treatment over control (78\%) and in general over all other treatments. The above-mentioned results are in consonance with those obtained by Soliman and Mahmoud (2013) on Adansonia digitata $\mathrm{L}$.

The stimulated effects of mixed treatment (HNB) may be attributed to the production of phytohormones from biofertilisers as mentioned by Mehnaz et al. (2001) who reported that IAA produced by rhizobacteria as plant growth promoting Rhizobacteria PGPR is believed to increase root growth and root length, resulting in better nutrient uptake from soil. Also Marek and Skorupska (2001) provided evidence that four different forms of GA are produced by many Bacillus sp., which effectively reverses a chemical-induced inhibition of stem growth, working together in the presence of organic

$\mathrm{T}$ a

Effect of different treatments on percentage essential oil constitutes of caraway plant during two seasons 2013 and 2014

\begin{tabular}{|l|c|r|r|r|r|r|r|r|r|r|}
\hline \multirow{2}{*}{ Treatment } & \multicolumn{2}{|c|}{ NPK } & \multicolumn{2}{c|}{$\begin{array}{c}\text { Humic substances } \\
(\mathrm{H})\end{array}$} & \multicolumn{2}{c|}{ Nano Zeolite (N) } & \multicolumn{2}{c|}{ Biofertilisers (B) } & \multicolumn{3}{c|}{ HNB } \\
\hline Components [\%] & \multicolumn{1}{|c|}{$\mathrm{F}$} & $\mathrm{S}$ & $\mathrm{F}$ & $\mathrm{S}$ & $\mathrm{F}$ & $\mathrm{S}$ & $\mathrm{F}$ & $\mathrm{S}$ & $\mathrm{F}$ & $\mathrm{S}$ \\
\hline$\alpha$-pinene & 0.244 & 0.211 & 0.321 & 0.305 & 0.421 & 0.436 & 0.295 & 0.358 & 0.441 & 0.506 \\
Camphene & 0.364 & 0.297 & 0.391 & 0.331 & 0.305 & 0.479 & 0.405 & 0.412 & 0.351 & 0.401 \\
Carvone & 80.38 & 78.11 & 75.08 & 73.56 & 82.38 & 80.09 & 70.48 & 75.95 & 77.62 & 84.35 \\
$\beta$-Pinene & 0.38 & 0.33 & 0.310 & 0.36 & 0.28 & 0.35 & 0.26 & 0.24 & 0.34 & 0.32 \\
Limonene & 7.97 & 8.52 & 10.29 & 10.06 & 9.56 & 9.24 & 15.41 & 11.58 & 8.91 & 6.73 \\
Linalool & 0.01 & 0.01 & 0.020 & 0.04 & 0.03 & 0.02 & 0.04 & 0.05 & 0.03 & 0.04 \\
$\beta$-Selinene & 0.50 & 0.51 & 0.590 & 0.65 & 0.54 & 0.53 & 0.6 & 0.58 & 0.56 & 0.55 \\
$\alpha$-Selinene & 0.38 & 0.36 & 0.250 & 0.23 & 0.24 & 0.21 & 0.27 & 0.23 & 0.26 & 0.25 \\
$\alpha$-Terpineol & 0.01 & 0.01 & 0.020 & 0.02 & 0.03 & 0.01 & 0.03 & 0.02 & 0.00 & 0.00 \\
Unknown & 0.31 & 0.29 & 0.410 & 0.39 & 0.52 & 0.49 & 0.25 & 0.23 & 0.58 & 0.61 \\
Unknown & 0.03 & 0.05 & 0.060 & 0.08 & 0.07 & 0.06 & 0.04 & 0.05 & 0.09 & 0.08 \\
Unknown & 0.00 & 0.00 & 0.000 & 0.02 & 0.01 & 0.01 & 0.00 & 0.00 & 0.02 & 0.03 \\
\hline
\end{tabular}

$\mathrm{F}$ - first season; $\mathrm{S}$ - second season 
matter present in humic substances, which is considered a source of hormone-like substances.

\section{Effect on essential oil productivity}

The data of essential oil yield as yellow colour and aromatic spicy odour are shown in Figures 5 and 6 . The combination of humic substances, nano-zeolite-loaded nitrogen and biofertilisers (HNB) treatment significantly resulted in rising essential oil yield either per plant or per hectare in comparison with control since they recorded $28 \%$ and $50 \%$, respectively for the first season and $30 \%$ and $53 \%$, respectively for the second one. On the other hand, the lowest significant result of essential oil yield was recorded with biofertiliser treatment alone compared with all other treatments and particularly control plants (61\% and 52\%) and (75\% and 58\%) for both seasons respectively.

The increase in essential oil productivity with mixed treatment (HNB) over all other treatments including control treatment could be explained on the basis of available elements, vitamins, hormone-like substances, amino acids and sugars, which have a significant effect on the physiological or biochemical processes within the plant (the case of luxury of metabolism) and consequently boost essential oil yield. These results coincide with those obtained by Mahmoud (2012) on yarrow plant (Achillea millefolium) who stated that application of compost mixed with zeolite, humic acids and biofertilisers increased oil yield.

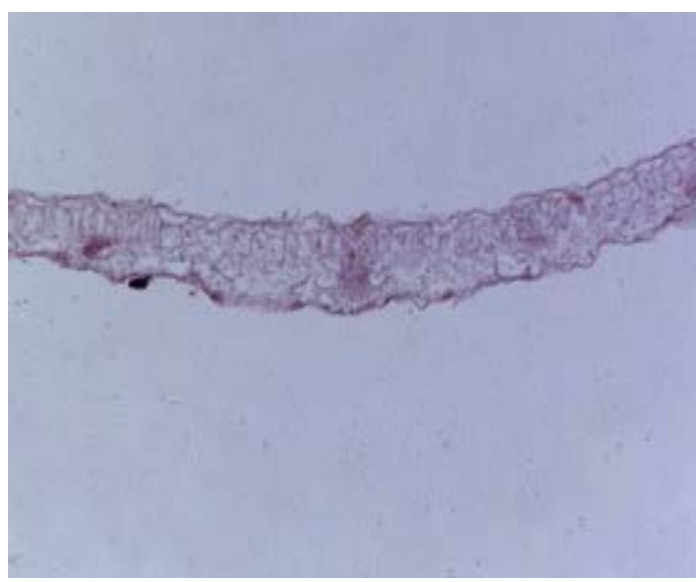

(a)

\section{Effect on essential oil constitutes}

The data for essential oil components are presented in Table 10. It clearly=indicates that mixed treatment (HNB), particularly in the second season, resulted in the highest percentage of carvone $(84.35 \%)$ and $\alpha$-pinene $(0.506 \%)$ over all treatments including control plants. While the lowest percentage of carvone $(70.48 \%$ ) was obtained from biofertilisers, but unexpected results were obtained from biofertiliser treatment alone since it gave the highest percentage of limonene (15.41\%) compared to either control or all other treatments.

With components, we found that the highest percentage of camphene $(0.479 \%)$ resulted in the second season as a result of nano-zeolite treatment, while humic substances alone gave the highest percentage of $\beta$-selinene $(0.65 \%)$ in the second season. But the highest percentage of $\alpha$-selinene $(0.38 \%$ and $0.36 \%$, respectively) was obtained from control plants in both seasons. The aforesaid results are in concurrence with those of Sedláková et al. (2003) who mentioned that carvone and limonene account for the main proportion, that is, about $95 \%$ of caraway essential oil components. However, Jalali-Heravi et al. (2007) reported that the major constituents in caraway seeds were terpinene (24.40\%), 2-methyl-3-phenylpropanal $\quad(13.20 \%)$ and 2,4(10)-thujadien (14.02\%).

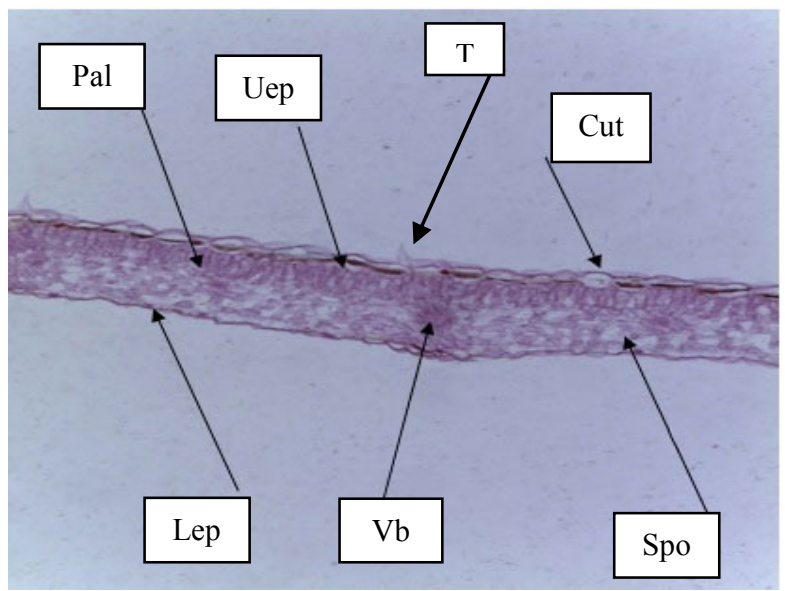

(b)

Figure 7. Leaves: (Pal) palisade; (Uep) upper epidermis; (T) trichomes, (Cut) cuticle; (Lep) lower epidermis; (Vb) vascular bundle; (Spo) spongy tissue 
Effect of different treatments on anatomical structure (leaves and seeds) of caraway plant

\section{Effect on leaves}

Generally caraway leaves are dorsiventral where the palisade tissue is located on the adaxial side of the blade and the spongy tissue on the abaxial one. Compact arrangement of epidermal cells and the presence of cuticle layer, stomata and trichomes are the main features of epidermis.

As revealed in Figure $7 \mathrm{a}$ and $7 \mathrm{~b}$, the epidermis cells of the control (Figure 7a) were similar in shape and size, while the epidermal cells of the HNB-treated leaves (Figure 7b) became larger in size and reached a maximum size. Additionally, it was remarkable that the thickness of mesophyll tissue, which specializes in photosynthesis and con- tains chloroplasts in palisade, and size of spongy parenchyma tissue, air spaces and trichomes after HNB treatment became larger compared to control. Moreover, vascular bundles of the principal veins, which are accompanied from above and below by parenchyma tissue in which a secretory canal lies above and below the vein were larger and greater in HNB treatment leaves compared to control leaves. All these findings were clear based on the chlorophyll concentration, which was higher in HNB treatment leaves compared to control.

This confirmed the profitable effect of mixed treatment of HNB on the anatomical structure of caraway leaves. In this sense, these data were similar to those obtained by El-Feky et al. (2013) on basil who found that foliar application of nano $\mathrm{Fe}_{3} \mathrm{O}_{4}$ improved anatomical structure of leaves.

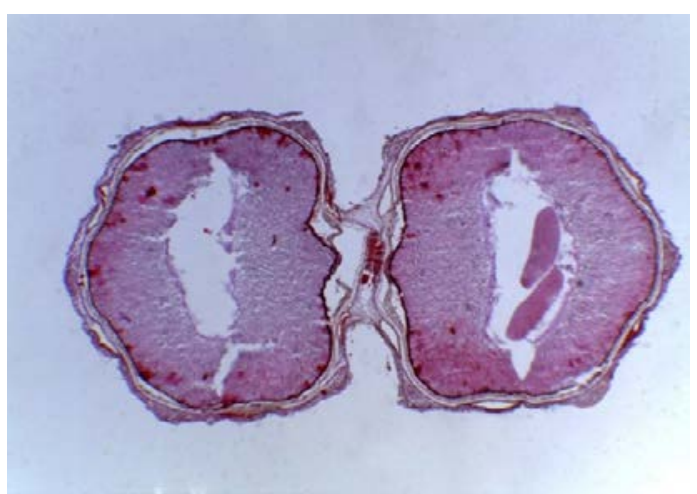

(a)

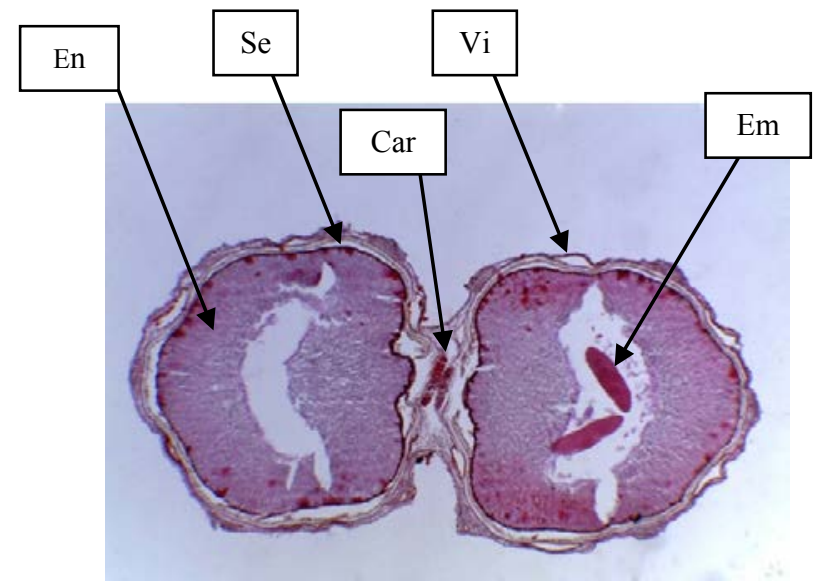

(b)

Figure 8. Seed: (En) endosperm; (Se) seed coat; (Car) carpophores; (Vi) vittae, (Em) embryo

$\mathrm{T}$ a $\mathrm{b} 1 \mathrm{e} \quad 11$

Economical evaluation of different treatments

\begin{tabular}{|l|c|c|c|c|c|c|c|c|}
\hline Treatments & $\begin{array}{c}\text { Total yield } \\
{[\mathrm{L} / \mathrm{ha}]}\end{array}$ & $\begin{array}{c}\text { Total } \\
\text { production } \\
\text { cost } \\
\text { [US dollar/ha] }\end{array}$ & $\begin{array}{c}\text { Gross income } \\
\text { [US dollar/ha] }\end{array}$ & $\begin{array}{c}\text { Profitable } \\
\text { return } \\
\text { (PR) } \\
\text { [US dollar/ha] }\end{array}$ & $\begin{array}{c}\text { PR } \\
\text { over control } \\
\text { [US dollar/ha] }\end{array}$ & $\begin{array}{c}\text { PR\% } \\
\text { increase } \\
\text { [US dollar/ha] }\end{array}$ & BCR & IF \\
\hline NPK as control & 29.75 & 315 & 17,850 & 17,535 & - & - & - & 56.6 \\
Humic substances & 29.36 & 241 & 17,616 & 17,375 & 160 & 1.0 & 0.66 & 73.0 \\
Nano-zeolite & 34.77 & 240 & 20,862 & 20,622 & 3,087 & 17.6 & 12.8 & 87.0 \\
Biofertilisers & 18.34 & 238 & 11,004 & 10,766 & 6,769 & 38.6 & 28.4 & 46.2 \\
HNB & 55.85 & 304 & 33,510 & 33,206 & 15,671 & 89.3 & 51.5 & 110.0 \\
\hline
\end{tabular}




\section{Effect on seeds}

Caraway fruit is a schizocarp (cremocarp) consisting of two mericarps. Each mericarp has two (sometimes three) large vittae on the commissural surface and about 20 to 30 small vittae on the dorsal surface. Between the vittae, the pericarp is ridged externally and a vascular strand is contained in each of these ridges.

The seed contains a small dicotyledonous embryo at the apical end, embedded in an abundant oily endosperm (Parry 1945). It was found that vittae size and numbers in fruits were higher in HNB treatment (Figure 8b) in comparison with control (Figure 8a). These findings confirm the beneficial role of the mix of humic substances, nano-zeolite-loaded nitrogen and biofertilisers on anatomical structure and oil yield as mentioned before. The obtained results are in agreement with Nassar et al. (2001) on anise.

\section{Economical evaluation}

Data in Table 11 undoubtedly explained that chemical fertilisers resulted in a maximum production cost of US\$315/hectare. On the other hand, the minimum production cost of biofertiliser treatment was US $\$ 238 /$ hectare. Meanwhile, a combination of humic substances, nano-zeolite-loaded nitrogen and biofertilisers (HNB) gave the maximum gross income of $\$ 33,510 /$ hectare, profitable return (PR) of $\$ 33,206 /$ hectare and benefit-cost ratio (BCR) 51.5. On the subject of investment factor (IF), the highest IF value (110) was recorded in the combination treatment (HNB). Generally, data analysis revealed that the cost of commercial production of caraway plant (Carum carvi L.) varied among treatments. In the interim, all treatments realized reasonable profitability since their IF is more than 3 (FAO 2000).

\section{CONCLUSIONS}

On the basis of previously mentioned data, which lead to the conclusion that application of humic substances, natural nano-zeolite-loaded nitrogen and biofertilisers mixture (HNB) gave good results on either plant under investigation caraway (Carum carvi L.) and environment that presents with higher growth characteristics and chemical composition in comparison with results derived from chemical fertilisers NPK considering both quality and quantity. Meanwhile it was clear that economic evaluation showed a beneficial profitable return, which increases the income of farmers and producers. This influential mixture (HNB), which is inexpensive, could replace the chemical fertilisers used for plant growth enhancement. In a nutshell, application of organic fertilisers, natural soil amendments and near to the ground quantity of chemical fertilisers (nano form) could bring good economic benefits and multiple advantages for consumers, producers, farmers and our ecosystem.

\section{REFERENCES}

AL-QADSIA, A.S. 2004. Effect of Biofertilization on Ocimum basilicum L. Plant. M.Sc. Thesis, Fac. Agric., Cairo Univ., Egypt, 136 p.

ALZOREKY, N.S. - NAKAHARA, K. 2003. Antibacterial activity of extracts from some edible plants commonly consumed in Asia. In International Journal of Food Microbiology, vol. 80, no. 3, pp. 223-230.

ASAMI, D.K. - HONG, Y.J. - BARRETT, D.M. - MITCHELL, A.E. 2003. Comparison of the total phenolic and ascorbic acid content of freeze-dried and air-dried marionberry, strawberry, and corn grown using conventional, organic, and sustainable agricultural practices. In Journal of Agricultural and Food Chemistry, vol. 51, no. 5, pp. 1237-1241.

BELLALOUI, N. - MENGISTU, A. - ZOBIOLE, L.H.S. SHIER, W.T. 2012. Resistance to toxin-mediated fungal infection: role of lignins, isoflavones, other seed phenolics, sugars, and boron in the mechanism of resistance to charcoal rot disease in soybean. In Toxin Reviews, vol. 31, no. 1-2, pp. 16-26.

BELLALOUI, N. - REDDY, K.N. - GILLEN, A.M. - FISHER, D.K. - MENGISTU, A. 2011. Influence of planting date on seed protein, oil, sugars, minerals, and nitrogen metabolism in soybean under irrigated and non-irrigated environments. In American Journal of Plant Sciences, vol. 2, no. 05, p. 702 .

BERNARDI, A.C.C. - WERNECK, C.G. - HAIM, P.G. - REZENDE, N.G.A.M. - PAIVA, P. R.P. - MONTE, M.B.M. 2008. Growth and mineral nutrition of Rangpur Lime rootstock cultivated in substrate with zeolite enriched with NPK. In Revista Brasileira de Fruticultura, vol. 30, no. 3, pp. 794-800. http://dx.doi.org/10.1590/S010029452008000300039

CECCHI, G. - BIASINI, S. - CASTANO, J. 1985. Méthanolyse rapide des huiles en solvant: note de laboratoire. In Revue Française des Corps Gras, vol. 32, no. 4, pp. 163-164.

DARDANELLI, J.L. - BALZARINI, M. - MARTÍNEZ, M.J. - CUNIBERTI, M. - RESNIK, S. - RAMUNDA, S.F. HERRERO, R. - BAIGORRI, H. 2006. Soybean maturity groups, environments, and their interaction define mega-environments for seed composition in Argentina. In Crop Science, vol. 46, no. 5, pp. 1939-1947.

DUMAS, Y. - DADOMO, M. - DI LUCCA, G. - GROLIER, P. 2003. Effects of environmental factors and agricultural techniques on antioxidant content of tomatoes. In Journal 
of the Science of Food and Agriculture, vol. 83, no. 5, pp. 369-382.

ELFEKY, S.A. - MOHAMMED, M.A. - KHATER, M.S. OSMAN, Y.A. H. - ELSHERBINI, E. 2013. Effect of magnetite Nano-Fertilizer on Growth and yield of Ocimum $b a$ silicum L. In International Journal of Indigenous Medicinal Plants, vol. 46, no. 3, pp. 1286-1293.

EL-FEKY, S.A. - MOHAMMED, M.A. - KHATER, M.S. OSMAN, Y.A. - ELSHERBINI, E. 2013. Effect of magnetite nano-fertilizer on growth and yield of Ocimum basilicum L. In International Journal of Indigenous Medicinal Plants, vol. 46, no. 3, pp. 1286-1293.

EL-ZEMITY, S.R. - REZK, H.A. - ZAITOON, A.A. 2006. Acaricidal activity of some essential oils and their monoterpenoidal constituents against the parasitic bee mites, Varroa destructor (Acari: Varroidae). In Journal of Applied Sciences Research, vol. 2, no.11, pp.1032-1036.

ENE, A.C. - NWANKWO, E.A. - SAMDI, L.M. 2008. Alloxaninduced diabetes in rats and the effects of black caraway (Carum carvi L.) oil on their body weight. In Journal of Pharmacology and Toxicology, vol. 3, no. 2, pp. 141-146.

FALES, H.M. - JAOUNI, T.M. - BABASHAK, J.F. 1973. Simple device for preparing ethereal diazomethane without resorting to codistillation. In Analytical Chemistry, vol. 45, no. 13 , pp. 2302-2303.

FAO 2000. Fertilizers and their use. $4^{\text {th }}$ edition: handbook was prepared originally for use by extension officers working for the FAO Fertilizer Programme. Rome : FAO, p. 34.

FAO 2013. Food and Agriculture Organization of the United Nations. http://www.fao.org/home/en/.

FEWTRELL, L. 2004. Drinking-Water nitrate, methemoglobinemia, and global burden of diasease: A Discusion. In Environmental Health Perspectives, vol. 112 , no. 14, pp. 1371-1374. DOI: 10.1289/ehp.7216

HARTMANS, K.J. - DIEPENHORST, P. - BAKKER, W. GORRIS, L.G. 1995. The use of carvone in agriculture: sprout suppression of potatoes and antifungal activity against potato tuber and other plant diseases. In Industrial Crops and Products, vol. 4, no.1, pp. 3-13.

HASSAN, A.Z.A. - GHALLAB-MAHMOUD, A.W.M. GHOBASHY, A.M. 2006. Response or rosemary plants to organic and inorganic biofertilizer in replacement of chemical fertilization. In Journal of Environmental Sciences, vol. 4, no. 2, pp. 527-544.

HASSAN, A.Z.A. - MAHMOUD, A.W.M. 2015. Hydrothermal synthesis of nano crystals (AM) zeolite using variable temperature programs. In Journal of Nanomaterials \& Molecular Nanotechnology, 4:4. DOI:10.4172/23248777.1000168

HELRICH, K. 1990. Official methods of analysis, 15th ed. Arlington, USA : Association of Official Agricultural Chemist. vol. 1, p. 673.

JACKSON, M.L. 1973. Soil Chemical Analysis. New Delhi : Printice-Hall of India. Privat Limited, New Delhi. Text book. pp. 144-197, 381.

JALALI-HERAVI, M. - ZEKAVAT, B. - SERESHTI, H. 2007. Use of gas chromatography-mass spectrometry combined with resolution methods to characterize the essential oil components of Iranian cumin and caraway. In Journal of Chromatografy A, vol. 1143, no. 1-2, pp. 215-226. http:// doi.org/10.1016/j.chroma.2007.01.042

JIN, S.J. - WANG, C. - ZHANG, Q. - SHANG, K.K. ZHANG, D.S. 2008. Influences of different treatment on soil conditions and plant physiological characters. In Journal of Zhejiang Forestry Science and Technology, no. 2, p. 38-42.
JOHANSEN, D.A. 1940. Plant microtechnique. London : McGraw Hill Publishing, Company Ltd., 523 pp.

KALLO, D. - PAPP, J. - TERBE, I. 1986. Horticultural use of zeolite minerals. In Kerteszeti-Egyetem-Kozlemenyei Publication, vol. 50, no.18, pp. 47-56.

KAMALEESWARI, M. - DEEPTHA, K. - SENGOTTUVELAN, M. - NALINI, N. 2006. Effect of dietary caraway (Carum carvi L.) on aberrant crypt foci development, fecal steroids, and intestinal alkaline phosphatase activities in 1, 2-dimethylhydrazine-induced colon carcinogenesis. In Toxicology and applied pharmacology, vol. 214, no. 3, pp. 290-296.

KELKAR, A.J. - HERR, D.J.C - RYAN, J.G 2014. Nanoscience and Nanoengineering: Advances and Applications. Boca Raton : CRC Press, Taylor and Francis Group, p. 331. ISBN 978-1-4822-3119-9

KHODAKOVSKAYA, M.V. - DE SILVA, K. - BIRIS, A.S. DERVISHI, E. - VILLAGARCIA, H. 2012. Carbon nanotubes induce growth enhancement of tobacco cells. In $A C S$ nano, vol. 6 , no. 3, pp. 2128-2135.

KRAVCHENKO, A.N. - BULLOCK, D.G. 2002. Spatial variability of soybean quality data as a function of field topography. In Crop Science, vol. 42, no. 3, pp. 804-815.

KUMAR, P. - SINGH, D.K. 2006. Molluscicidal activity of Ferula asafoetida, Syzygium aromaticum and Carum carvi and their active components against the snail Lymnaea acuminata. In Chemosphere, vol. 63, no. 9, pp. 1568-1574.

LAHLOU, S. - TAHRAOUI, A. - ISRAILI, Z. - LYOUSSI, B. 2007. Diuretic activity of the aqueous extracts of Carum carvi and Tanacetum vulgare in normal rats. In Journal of Ethnopharmacology, vol. 110, no. 3, pp. 458-463.

LAWLESS, J. 1992. The Encyclopaedia of Essential Oils: The Complete Guide to the Use of Aromatics in Aromatherapy, Herbalism and Well-being. Element Books. Longmead, Shaftesbury, Dorset.

LECLERC, J. - MILLER, M.L. - JOLIET, E. - ROCQUELIN, G. 1991. Vitamin and mineral contents of carrot and celeriac grown under mineral or organic fertilization. In Biological Agriculture \& Horticulture, vol. 7, no. 4, pp. 339-348.

LEMHADRI, A. - HAJJI, L. - MICHEL, J.B. - EDDOUKS, M. 2006. Cholesterol and triglycerides lowering activities of caraway fruits in normal and streptozotocin diabetic rats. In Journal of ethnopharmacology, vol. 106, no. 3, pp. 321-326.

LI, J. - WEE, C. - SOHN, B. 2013. Effect of ammonium-and potassium-loaded zeolite on kale (Brassica alboglabra) growth and soil property. In American Journal of Plant Sciences, vol. 4, no. 10, p. 1976.

LI, Z. 2003. Use of surfactant-modified zeolite as fertilizer carriers to control nitrate release. In Microporous and Mesoporous Materials, vol. 61, no. 1, pp. 181-188.

LOPEZ, M.D. - JORDÁN, M.J. - PASCUAL-VILLALOBOS, M.J. 2008. Toxic compounds in essential oils of coriander, caraway and basil active against stored rice pests. In Journal of Stored Products Research, vol. 44, no. 3, pp. 273-278.

MA, X. - GEISER-LEE, J. - DENG, Y. - KOLMAKOV, A. 2010. Interactions between engineered nanoparticles (ENPs) and plants: phytotoxicity, uptake and accumulation. In Science of Total Environment, vol. 408, no. 16, pp. 3053-3061.

MAHMOUD, A.W.M. 2012. Physiological effects of zeolite and organic fertilizers on yarrow plant grown under clean agriculture conditions. PhD. Thesis, Plant Physiology Department, Fac. Agric., Cairo Univ., Egypt, 297 p.

MAREK-KOZACZUK, M. - SKORUPSKA, A. 2001. Production of B-group vitamins by plant growth-promoting Pseudomonas fluorescens strain 267 and the importance of 
vitamins in the colonization and nodulation of red clover. In Biology and Fertility of Soils, vol. 33, no. 2, pp. 146-151.

MEDA, A. - LAMIEN, C.E. - ROMITO, M. - MILLOGO, J. - NACOULMA, O.G. 2005. Determination of the total phenolic, flavonoid and proline contents in Burkina Fasan honey, as well as their radical scavenging activity. In Food chemistry, vol. 91, no. 3, pp. 571-577.

MEHNAZ, S. - MIRZA, M.S. - HAURAT, J. - BALLY, R. - NORMAND, P. - BANO, A. - MALIK, K.A. 2001. Isolation and $16 \mathrm{~S}$ rRNA sequence analysis of the beneficial bacteria from the rhizosphere of rice. In Canadian journal of microbiology, vol. 47, no. 2, pp.110-117.

MONNIER, J.B. - DUPONT, M. 1983. Zeolite-water close cycle solar refrigeration; numerical optimisation and field-testing. In Proceeding American Solar Energy Society meeting; 1 June Minneapolis, MN, USA. Vol/Issue: 6, pp. 181-185.

MORAN, R. 1982. Formulae for determination of chlorophyllous pigments extracted with $\mathrm{N}, \mathrm{N}$-dimethylformamide. In Plant physiology, vol.69, no. 6, pp. 1376-1381.

MUBASHIR, M. - MALIK, S.A. - KHAN, A.A. - ANSARI, T.M. - WRIGHT, S. - BROWN, M.V. - ISLAM, K.R. 2010. Growth, yield and nitrate accumulation of irrigated carrot and okra in response to nitrogen fertilization. In Pakistan Journal of Botany, vol. 42, no. 4, pp. 2513-2521.

NADERI-KALALI, B. - ALLAMEH, A. - RASAEE, M.J. BACH, H.J. - BEHECHTI, A. - DOODS, K. - KETTRUP, A. - SCHRAMM, K.W. 2005. Suppressive effects of caraway (Carum carvi) extracts on 2, 3, 7, 8-tetrachloro-dibenzo-p-dioxin-dependent gene expression of cytochrome P450 1A1 in the rat H4IIE cells. In Toxicology in vitro, vol. 19, no. 3, pp. 373-377.

NASSAR, M.A. - EL-SAHHAR, K.F. - DALIA, M.N. 2001. Morphological and anatomical studies of Pimpinella anisum L. (Apiaceae) IV. Anatomical structure of leaves, flower and fruits. Bull. Fac. Agric., Cairo Univ., vol. 52, pp. 557-572.

OMAR, N.F. - HASSAN, S.A. - YUSOFF, U.K. ABDULLAH, N.A.P. - WAHAB, P.E.M. - SINNIAH, U.R. 2012. Phenolics, flavonoids, antioxidant activity and cyanogenic glycosides of organic and mineral-base fertilized Cassava Tubers. In Molecules, vol. 17, pp. 2378-2387.

OOSTERHAVEN, K. - POOLMAN, B. - SMID, E.J. 1995. S-carvone as a natural potato sprout inhibiting, fungistatic and bacteristatic compound. In Industrial Crops and Products, vol.4, no. 1, pp. 23-31.

PARRY, J.W. 1945. The spice handbook (spice, aromatic seeds and herbs). Brooklyn, N.Y.: Chemical publ. Co. Inc., 254 pp.

PIPER, C.S. 1950. Soil and plant analysis. Univ. Adelied. Intersciece Published, Inc. New York, p. 258-275.

PITASAWAT, B. - CHAMPAKAEW, D. - CHOOCHOTE, W. - JITPAKDI, A. - CHAITHONG, U. - KANJANAPOTHI, D. - RATTANACHANPICHAI, E. - TIPPAWANGKOSOL, P. - RIYONG, D. - TUETUN, B. - CHAIYASIT, D. 2007. Aromatic plant-derived essential oil: an alternative larvicide for mosquito control. In Fitoterapia, vol. 78, no. 3, pp. 205-210.

RANJBAR, M. - ESFAHANY, M. - KAVOUSI, M. YAZDANI, M.R. 2004. Effect of irrigation and natural zeolite application on yield and quality of tobacco (Nicotiana tabaccum var. Coker 347). In Journal of Agriculture Sciences, vol. 1, no. 2, pp. 71-84.

RAPALA-KOZIK, M. - KOWALSKA, E. - OSTROWSKA, K. 2008. Modulation of thiamine metabolism in Zea mays seedlings under conditions of abiotic stress. In Journal of experimental botany, vol. 59, no. 15, pp. 4133-4143.
RICHARDS, L.S. 1954. Diagnosis and Improvement of Saline and Alkaline Soils. U.S. Dept. Agric. Handbook No. 60.

RYAKHOVSKAYA, N.I. - GAINATULINA, V.V. 2009. Potato and oat yield in short- cycle crop rotation with zeolite application. In Russian Agricultural Sciences, vol. 35, no. 3, pp. $153-155$.

SARWAR, G. - HUSSAIN, N. - SCHMEISKY, H. MUHAMMAD, S. - IBRAHIM, M. - SAFDAR, E. 2007. Use of compost an environment friendly technology for enhancing rice-wheat production in Pakistan. In Pakistan Journal of Botany, vol. 39, no. 5, pp.1553-1558.

SAVCI, S. 2012. Investigation of effect of chemical fertilizers on environment. In Apcbee Procedia, vol. 1, pp. 287-292.

SEDLÁKOVÁ, J. - KOCOURKOVÁ, B. - LOJKOVÁ, L. KUBAN, V. 2003. Determination of essential oil content in caraway (Carum carvi L.) species by means of supercritical fluid extraction. In Plant Soil and Environment, vol. 49, no. 6, pp. 277-282.

SIDDIQUI, M.H. - AL-WHAIBI, M.H. - MOHAMMAD, F. 2015. Nanotechnology and Plant Sciences. Springer Interna tional Publishing, 303 p. DOI: 10.1007/978-3-319-14502-0

SIMPSON, A.M. - WILCOX, J.R. 1983. Genetic and phenotypic associations of agronomic characteristics in four high protein soybean populations. In Crop Science, vol. 23, no. 6, pp.1077-1081.

SINGLETON, V.L. - ROSSI, J.A. 1965. Colorimetry of total phenolics with phosphomolybdic-phosphotungstic acid reagents. In American journal of Enology and Viticulture, vol. 16, no. 3, pp. 144-158.

SINKOVIČ, L. - ŽNIDARČIČ, D. 2016. Impact of organic fertilizers on phenolic profiles and fatty acids composition: A case study for Cichorium intybus L. In Organic fertilizers - From Basic Concepts to Applied Outcomes, p. 309-330. DOI: $10.5772 / 62325$

SOLIMAN, A. SH. - MAHMOUD, A.W.M. 2013. Response of Adansonia digitata to compost and zeolite in replacement of chemical fertilization. In American-Eurasian Journal of Agricultural \& Environmental Sciences, vol. 13, no. 2, pp. 198-206. DOI: 10.5829/idosi.aejaes.2013.13.02.6213

SOLIMAN, K.M. - BADEAA, R.I. 2002. Effect of oil extracted from some medicinal plants on different mycotoxigenic fungi. In Food and Chemical Toxicology, vol. 40, pp. 1669-1675.

TISDALE, S.L. - NELSON, W.L. 1975. Soil Fertility and Fertilizers, $3^{\text {rd }}$ Edition. Macmillan Publishing, New York, USA. 694 pp.

VOGEL, A.I. 1975. A text book of practical organic chemistry. Published by English Language Book society and Longman Group Limited $3^{\text {rd }}$ Ed., pp. 197-596.

WOJDYŁO, A. - OSZMIAŃSKI, J. - CZEMERYS, R. 2007. Antioxidant activity and phenolic compounds in 32 selected herbs. In Food chemistry, vol. 105, no. 3, pp. 940-949.

YU, L.L. - ZHOU, K.K. - PARRY, J. 2005. Antioxidant properties of cold-pressed black caraway, carrot, cranberry, and hemp seed oils. In Food chemistry, vol. 91, no. 4, pp.723729.

Received: February 10, 2017 